\title{
Bivalve Feeding Responses to Microalgal Bloom Species in the Indian River Lagoon: the Potential for Top-Down Control
}

\author{
Eve Galimany ${ }^{1,2}$. Jessica Lunt ${ }^{1,3} \cdot$ Christopher J. Freeman $^{1,4} \cdot$ Jay Houk $^{1} \cdot$ Thomas Sauvage $^{1,5} \cdot$ Larissa Santos $^{1}$. \\ Jillian Lunt ${ }^{1} \cdot$ Maria Kolmakova ${ }^{1} \cdot$ Malcolm Mossop $^{1} \cdot$ Arthur Domingos $^{1} \cdot$ Edward J. Phlips $^{6} \cdot$ Valerie J. Paul $^{1}$
}

Received: 6 January 2020 / Revised: 2 April 2020 / Accepted: 14 April 2020 / Published online: 23 April 2020

(C) The Author(s) 2020

\begin{abstract}
In 2011, the Indian River Lagoon, a biodiverse estuary in eastern Florida (USA), experienced an intense microalgal bloom with disastrous ecological consequences. The bloom included a mix of microalgae with unresolved taxonomy and lasted for 7 months with a maximum concentration of $130 \mu \mathrm{g}$ chlorophyll $a \mathrm{~L}^{-1}$. In 2012, brown tide Aureoumbra lagunensis also bloomed in portions of this estuary, with reoccurrences in 2016 and 2018. To identify and understand the role of grazer pressure (top-down control) on bloom formation, we coupled DNA sequencing with bivalve feeding assays using three microalgae isolated from the 2011 bloom and maintained in culture. Feeding experiments were conducted on widely distributed bivalve species in the lagoon, including eastern oysters (Crassostrea virginica), hooked mussels (Ischadium recurvum), charru mussels (Mytella charruana), green mussels (Perna viridis), Atlantic rangia (Rangia cuneata), and hard clams (Mercenaria mercenaria), which were exposed to $3 \times 10^{4}$ cells $\mathrm{mL}^{-1}$ of five species of microalgae consisting of A. lagunensis and the three species clarified herein, the picocyanobacteria Crocosphaera sp. and 'Synechococcus' sp., and the picochlorophyte Picochlorum sp., as well as Nannochloropsis oculata used as a control. To ensure clearance rates were indicative of consumption and assimilation, the microalgae were isotopically $\left({ }^{15} \mathrm{~N}\right)$ labeled prior to feeding experiments. Clearance rates differed among bivalve and microalgal species, but enriched ${ }^{15} \mathrm{~N}$ values in bivalve tissue suggest that algal bloom species were assimilated by the bivalves. These results expand our understanding of the important ecosystem services that healthy, biodiverse filter feeder communities provide.
\end{abstract}

Keywords Oysters $\cdot$ Mussels $\cdot$ Clams $\cdot$ Aureoumbra lagunensis $\cdot$ Synechococcus $\cdot$ Harmful algal bloom

\section{Introduction}

Marine coastal ecosystems are under increased threat from eutrophication that is fueled by anthropogenically derived

Eve Galimany and Jessica Lunt contributed equally to this work.

Communicated by Deana Erdner

Electronic supplementary material The online version of this article (https://doi.org/10.1007/s12237-020-00746-9) contains supplementary material, which is available to authorized users.

Eve Galimany

galimany@icm.csic.es

Jessica Lunt

jlunt@disl.org

1 Smithsonian Marine Station, 701 Seaway Dr, Fort Pierce, FL 34949, USA

2 Present address: Institute of Marine Sciences ICM-CSIC, P. Marítim Barceloneta 37-49, 08003 Barcelona, Spain inputs like sewage, animal waste, and fertilizer (Halpern et al. 2007). These excess nutrients can cause harmful algal blooms that have detrimental impacts on diverse ecosystems but have had an especially strong effect on estuaries (Capriulo
3 Present address: Dauphin Island Sea Lab, 101 Bienville Blvd, Dauphin Island, AL 36528, USA

4 Present address: Department of Biology, College of Charleston, Charleston, SC 29424, USA

5 Present address: Graduate Program in Ecology, Universidade Federal do Rio Grande do Sul, Porto Alegre, Rio Grande do Sul, Brazil

6 University of Florida School of Forest Resources and Conservation, 7922 NW 71st Street, PO Box 110600, Gainesville, FL 32653, USA 
et al. 2002; Landsberg 2002; Heisler et al. 2008; Smith and Schindler 2009; Bricker and Devlin 2011). For example, blooms of microalgae (i.e., phytoplankton) can cause diminished light penetration (Lapointe et al. 2020), toxin production (Masó and Garcés 2006), hypoxia (Kahru et al. 2020), and the alteration of food web relationships (Landsberg 2002).

In the continental USA, estuaries comprise more than $80 \%$ of the coastline along the Atlantic Ocean and Gulf of Mexico (Pinckney et al. 2001). Many of these estuaries have been experiencing declining water quality and eutrophication for decades (Pinckney et al. 2001; Bricker et al. 2008). The Indian River Lagoon (IRL) stretches $250 \mathrm{~km}$ along the central coast of eastern Florida and is considered of vital importance to maintaining biodiversity because it spans the transition from the subtropical environment of south Florida to the temperate ecosystems north of Florida (Swain 1995; Sime 2005). As such, the IRL not only provides habitats for species overlapping and converging at the edge of their distribution but also includes many rare tropical species that have limited distributions (Swain 1995; Sime 2005). However, local species richness has been suffering from a variety of threats related to human activities such as freshwater diversion for agriculture and eutrophication from coastal development (Dybas 2002; Adams et al. 2019). One of the threats was an algal bloom that began in the spring of 2011 and spread throughout the northern IRL, where it lasted for 7 months (SJRWMD 2012; Kamerosky et al. 2015; Phlips et al. 2015). The duration and composition of this bloom was unprecedented, with mean chlorophyll $a$ concentration peaking eightfold above commonly reported historical concentrations $\left(>50 \mu \mathrm{g} \mathrm{L}^{-1}\right.$ in most areas). The cascading effects of the bloom reduced light penetration, inducing severe decreases in the density and distribution of seagrasses (Phlips et al. 2011) and mass mortalities of fish and shellfish (Gobler et al. 2013). The 2011 bloom was dominated by several microalgae, including picoplanktonic cyanobacteria of unresolved identity and a chlorophyte tentatively assigned to the Pedinophyceae by Phlips et al. (2015). In 2012, "brown tide" blooms dominated by Aureoumbra lagunensis (Stockwell et al., 1997), were first observed in the Mosquito Lagoon, Banana River, and northern Indian River (Phlips and Badylak 2013; Phlips et al. 2015), then reoccurred in parts of the region in 2013, 2015, 2016, and 2018 (Phlips et al. 2019). Blooms of this pelagophyte were originally found in Laguna Madre (Texas) in 1990 (DeYoe et al. 1997; Buskey et al. 1998). Microalgal blooms are controlled by complex feedback loops that include regulation of algal growth via both nutrient levels (bottom up) and reduction of algal abundances due to grazers (top down) (Gobler et al. 2013). Loss of grazing pressure, because of a reduction in the abundance of benthic and epifaunal filter feeders, could indirectly promote the proliferation of algal blooms through positive feedback (Sunda et al. 2006). Thus, filter-feeding organisms, such as bivalves, may play a major role in preventing or remediating potential negative effects of microalgal proliferations.

Bivalves feed on suspended particulate matter including bacteria, phytoplankton, micro-zooplankton, and detritus (Gosling 2003). However, the ability of bivalves to clear suspended particles is related to food quality and quantity and varies by species (Widdows et al. 1979; Shumway et al. 1985; Galimany et al. 2017b). Moreover, bivalves may sort the cleared particles and reject them prior to ingestion in the form of pseudofeces, depending on various factors such as the concentration of particles filtered from suspension, the surface properties of the trapped particles, low nutritional value, or particle chemical properties (Kiørboe and Møhlenberg 1981; Ward and Shumway 2004; Rosa et al. 2013). Bivalve feeding improves water quality by removing suspended particles from the water column, and, through the production and deposition of biodeposits (feces and pseudofeces), couples pelagic productivity with the benthos (Dame 1993; Norkko et al. 2001). Unfortunately, bivalve populations are decreasing worldwide because of overharvesting and ecosystem degradation, including populations of the IRL (Beck et al. 2011), where their functional value in these ecosystems may not be fully realized anymore.

Eastern oyster (Crassotrea virginica) populations have severely decreased over the years in all areas of the IRL as a consequence of low salinity, overharvest, and habitat degradation (Wilson et al. 2005; Garvis et al. 2015). Hard clams (Mercenaria mercenaria) once thrived in the IRL and a clam fishery was sustained until 1985, when most clams died as a result of freshwater flowing into the clam beds from flood control canals (MacKenzie Jr et al. 2001). Several oyster restoration projects are ongoing in an attempt to revitalize the Lagoon ecosystem (Garvis et al. 2015); however, as in other shallow estuaries, oyster restoration is not always successful. Mercenaria mercenaria restoration efforts also began in 1997 (Arnold 2001), but the population has not yet recovered and clams are currently only found in low abundances. The populations of other native bivalve species are not well documented and their abundances unclear, though a diverse assemblage is present (Mikkelsen et al. 1995).

As coastal development, nutrient pollution, and microalgal blooms increase in the IRL, it is critical to assess the potential for filter feeding organisms like bivalves to control algal blooms via cell removal and assimilation. The molecular and taxonomic identity of these algal bloomforming species is also quite unclear, impeding their tracking and detection. In this context, our study exposed several bivalve species to pre-bloom concentrations $\left(10^{4}\right.$ cells $\mathrm{mL}^{-1}$ ) of microalgal species that formed the "super" bloom in 2011 and the brown tide in 2012. We focused on Aureoumbra lagunensis and three other species that had been isolated at the onset of the IRL 2011 bloom (two picocyanobacteria and a picochlorophyte) but had not been 
previously identified molecularly to resolve their taxonomy. Examination of clearance rates allowed us to determine if the bivalves removed the microalgae from the water column; however, since clearing the particles does not always indicate ingestion and assimilation of the algal cells by bivalves (Ward and Shumway 2004), the algae were also isotopically enriched to trace the transfer of algal-derived nitrogen atoms into bivalve tissue. Studying the feeding physiology of bivalves and its relationship with bloom-forming microalgae is essential to estimate their potential for the prevention and possible bioremediation of future blooms and their ecological contribution to IRL health.

\section{Materials and Methods}

\section{Experimental Bivalves}

All bivalves were collected within the Indian River Lagoon, Florida, under natural conditions from areas that were not known to have experienced blooms of the algal species being tested. Oysters (Crassostrea virginica (Gmelin, 1971)) were collected from the seawalls of Florida Atlantic UniversityHarbor Branch, Fort Pierce. Mussels, Ischadium recurvum (Rafinesque, 1820), and Atlantic rangia, Rangia cuneata (G. B. Sowerby I, 1832), were collected in Palm City, on mud flats exposed at low tide. Hard clams, Mercenaria mercenaria (Linnaeus, 1758), were obtained from Research Aquaculture Inc. in Stuart. Invasive mussels were collected in Jacksonville: Mytella charruana (d'Orbigny, 1842) from Lonnie Wurn Boat Ramp and Perna viridis (Linnaeus, 1758) from Huguenot State Park. Bivalve average $( \pm$ SE) shell lengths $(\mathrm{mm})$ were $51.1 \pm 1.8$ for $C$. virginica, $43.6 \pm 0.4$ I. recurvum, $36.0 \pm 1.0 R$. cuneata, $45.6 \pm$ 0.6 M. mercenaria, $29.1 \pm 1.3$ M. charruana, and $56.0 \pm 4.1$ $P$. viridis. All bivalves collected were cleaned of epiphytes and other encrusting organisms and kept in the laboratory in a flowing lagoon water system for at least 1 week prior to feeding experiments. Bivalves were maintained at $20^{\circ} \mathrm{C}$ and the salinities in which they were collected (R. cuneata $5 \mathrm{ppt}$, $M$. mercenaria, $I$. recurvum, and $C$. virginica $20 \mathrm{ppt}$; $M$. charruana and $P$. viridis $30 \mathrm{ppt}$ ), except for I. recurvum individuals, which were collected at 5 ppt but slowly acclimated to 20 ppt over the period of 2 weeks, as this is the salinity in which they were more likely to encounter the microalgal species. Rangia cuneata individuals were not acclimated to higher salinity because their physiology may be compromised at salinities higher than $15 \mathrm{ppt}$ (Cooper 1981). Bivalves were fed a mixture of Tetraselmis sp. (Oahu, HI) and Nannochloropsis oculata (both cultures purchased from AlgaGen Vero Beach, FL) twice daily until feeding experiments.

\section{Microalgal Cultures}

Cultures of the three microalgae used in the experiments (i.e., two picocyanobacteria, CYAN1 and CYAN2, and a picochlorophyte, CHLO1) were isolated from the Banana River region of the Indian River Lagoon ecosystem in the summer of 2011 during the bloom event. Cultures of the three taxa were shipped from the Phlips Laboratory (University of Florida) to Smithsonian Marine Station for molecular sequencing and feeding experiments. For DNA extraction, cells were pelleted by centrifugation and processed with a DNeasy Plant Mini Kit (Qiagen, Hilden, Germany). PCR was conducted with primers targeting 16S rDNA (106F and 781R, Nübel et al. 1997), and products were cloned with a pGEM-T Easy Vector Systems. Clones were grown overnight on LB agar plates containing $100 \mu \mathrm{g} \mathrm{mL}^{-1}$ ampicillin, $0.1 \mathrm{mM}$ IPTG, and $40 \mu \mathrm{g} \mathrm{mL}^{-1} \mathrm{X}$-Gal and colony PCR performed with M13 primers. Products harboring the correct insert size were then Sanger sequenced at the Laboratory of Analytical Biology (LAB, Smithsonian Institution, Washington, DC). Finally, chromatograms were assembled in Sequencher v5.1 and consensus sequences merged with datasets from recently published taxonomic revisions and environmental sequences retrieved from Genbank via BLASTn (Altschul et al. 1997) (Supplementary Table S1). Phylogenetic analyses were conducted with the GTR + I + $\mathrm{G}$ model of evolution in RAxML with 100 restarts to find the best tree and 1000 bootstrap replicates to determine branch support (Fig. 1). New 16S sequences were deposited in GenBank under accessions MN647759 and MN647762-MN647763. Additional algal DNA barcodes (tufA and 23S, e.g., Sauvage et al. 2016; Sherwood et al. 2017) were also produced but not analyzed herein. These were deposited as a genetic resource to facilitate detection of these taxa in future environmental assays (tufA: MN649823-MN649825 and 23S: MN647764 and MN649236-MN649237).

The fourth species tested in feeding assays, an Aureoumbra lagunensis culture (TBT, Texas Brown Tide), was provided by the University of Texas Marine Science Institute. It was previously isolated from the Laguna Madre (North Padre Island, Texas, April 1996) by Dr. Villarreal's laboratory (Buskey et al. 1998, 2001). Cultures of Tetraselmis sp. (Oahu, HI) and $N$. oculata were fed to bivalves prior to experiments, and $N$. oculata was also used as a control in the experiments. All cultures were maintained in Guillard's F/2 seawater media in a Percival Incubator (model I36VLC 8) subjected to light intensity of 20 $25 \mu \mathrm{mol} \mathrm{m} \mathrm{m}^{-2} \mathrm{~s}^{-1}$ on a $12 / 12$ diurnal cycle. In this system, diurnal temperatures reached $29{ }^{\circ} \mathrm{C}$, while temperatures at night were $26{ }^{\circ} \mathrm{C}$. 
Fig. 1 16S rDNA phylogeny of algal bloom species identified and tested in feeding assays in the present study. a CYAN1 as Crocosphaera sp., b CYAN2 as an unresolved representative of the Prochlorotrichaceae, temporarily named 'Synechococcus' sp., and c CHLO1 as Picochlorum sp. Note that bootstrap values below $60 \%$ are not shown. See Table S1 for a listing of GenBank accessions used to build each phylogenetic tree a

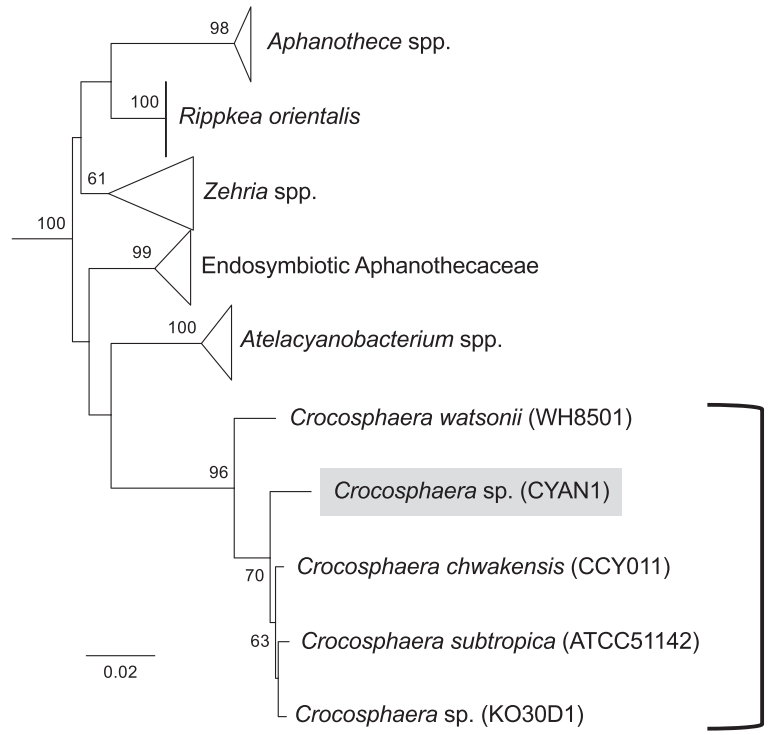

Crocosphaera spp.

b

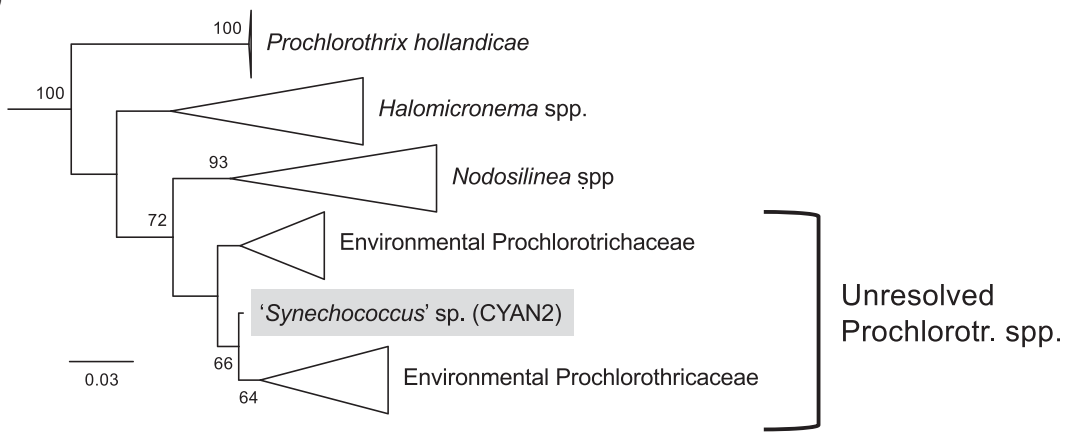

C

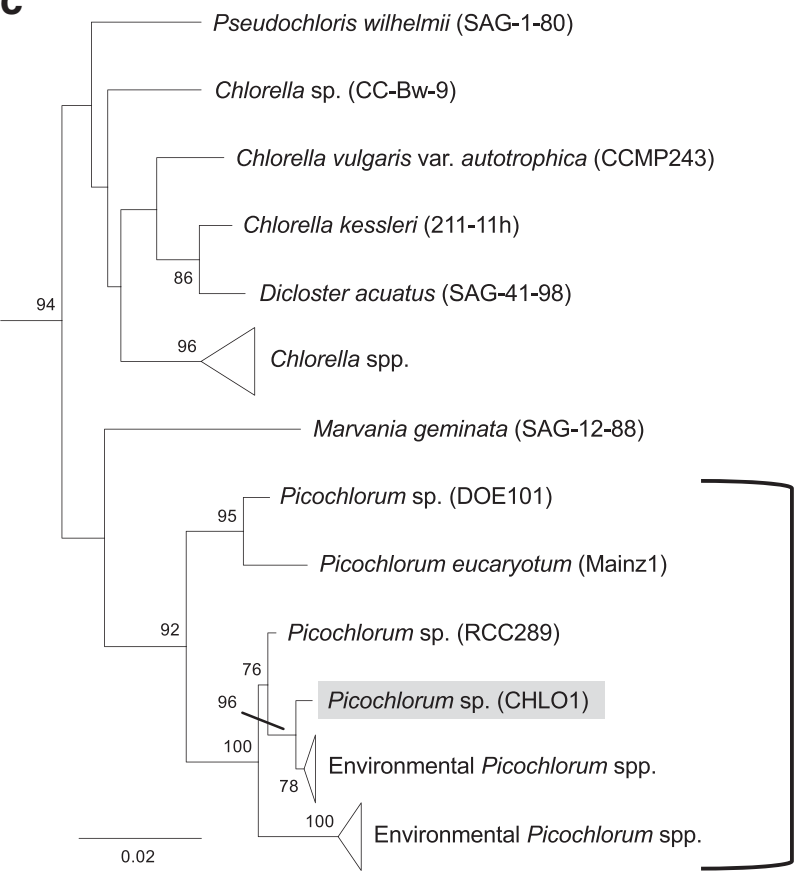

Picochlorum spp. 


\section{In Vivo Exposure Experimental Design}

Individuals were placed in $450 \mathrm{~mL}$ of filtered water adjusted to the salinity for each species prior to exposure with the treatment microalgae. Jars were aerated to maintain particle suspension; control jars set up in parallel without bivalves indicated that no significant sedimentation of algal cells took place within the jars. All species of bivalves were exposed to five treatments: (1) Nannochloropsis oculata (control), (2) Aureoumbra lagunensis, (3) the picochlorophyte CHLO1, (4) the picocyanobacteria CYAN1, and (5) the picocyanobacteria CYAN2. Nannochloropsis was chosen as a control over Tetraselmis because it was closer in size to the four experimental microalgal bloom species. Each algal culture was diluted with filtered seawater to $3 \times 10^{4}$ cells $\mathrm{mL}^{-1}$ and provided to bivalves twice a day. As all isolates were approximately the same size and shape $(5-6 \mu \mathrm{m}$ in diameter) we do not expect the biovolume of algae to differ across treatments with a standardized treatment. Each morning, bivalves were transferred to a container with filtered seawater. Meanwhile, the jar where the bivalve had been overnight was quickly emptied, washed, and filled with the corresponding algae and the bivalve returned. The process occurred quickly, and bivalves were transferred within $30 \mathrm{~s}$. In the afternoon, the algal concentration remaining in each jar was calculated using a C6 flow cytometer (BD Biosciences, San Jose, CA). Then, if the concentration in the jar was lower than $3 \times 10^{4}$ cells $\mathrm{mL}^{-1}$, the amount of microalgae needed was calculated and added. This was done to maintain a stable concentration of microalgae within each jar. To measure clearance rates, samples of water were collected from each jar on Day 0 (just after the first exposure to the microalgae) and after 4 days of exposure using the following sampling scheme on each day. Water samples $(1 \mathrm{~mL})$ were taken every $5 \mathrm{~min}$ for $30 \mathrm{~min}$ and then every $10 \mathrm{~min}$ for $30 \mathrm{~min}$ for ten samples per replicate over the course of an hour. This sampling regime accounts for the decrease in clearance rates as the particle concentration decreases. The water samples were preserved with a $1 \%$ formalin solution in DI water $(1.8 \mathrm{~mL}$ sample + $0.2 \mathrm{~mL}$ of $10 \%$ formalin). After the final exposure, bivalves were transferred to clean filtered seawater overnight to clear their digestive system, and then sacrificed. Soft tissue dry weight (following $24 \mathrm{~h}$ at $60{ }^{\circ} \mathrm{C}$ ) of all bivalves were measured. Each algal treatment had five to eight replicates for each species. Water samples were processed within 2 weeks using an Accuri C6 flow cytometer to calculate the suspended particles remaining in the samples.

\section{Clearance Rate Measurements}

Algal concentrations within each jar were determined using a C6 flow cytometer (BD Biosciences, San Jose, CA) for 2 min on the fast flow rate setting $\left(35 \mu \mathrm{L} \mathrm{min}{ }^{-1}\right)$. Algal cells were identified and quantified using plots contrasting side scatter (SSC) vs. blue fluorescence (FL3) and side scatter (SSC) vs. red fluorescence (FL4). Bivalve clearance rates were calculated from these data using the clearance method described by Coughlan (1969) and revised by Riisgård (2001). This method measures the filtration activity as the volume of water cleared of particles per unit of time. This is calculated from the exponential decrease in algal cell density as a function of time using the formula (Riisgård 2001):

$\mathrm{CR}=(V / n) \ln \left(C_{0} / C_{t}\right)$

where CR is the clearance rate, $V$ is the volume of water, $n$ is the number of animals (one per jar), and $C_{0}$ and $C_{t}$ are algal concentrations at time 0 and time $t$. All CR values were standardized to $1 \mathrm{~g}$ of dried bivalve flesh using the following equation:

$\mathrm{CR}_{\mathrm{s}}=\mathrm{CR} \times\left(1 / W_{\mathrm{e}}\right)^{\mathrm{b}}$

where $\mathrm{CR}_{\mathrm{s}}$ is the standardized clearance rate, $\mathrm{CR}$ is the experimentally determined clearance rate, and $W_{\mathrm{e}}$ is the average dry body mass measured for the bivalves. We used a predetermined feeding rate constant $\mathrm{b}$ value of 0.73 for oysters (C. virginica), 0.8 for clams (M. mercenaria and $R$. cuneata), and 0.83 for mussels (I. recurvum, M. charruana, and P. viridis) as described in Riisgård (1988) for C. virginica, M. mercenaria, and I. recurvum, respectively.

\section{Stable Isotopes}

To determine if algae were ingested and assimilated as a food source, cultures were isotopically labeled by incubation with inorganic tracer compounds enriched in the heavy isotopes of $\mathrm{C}$ and $\mathrm{N}$ (98 atom percent $($ at $\%){ }^{13} \mathrm{C}$ or ${ }^{15} \mathrm{~N}$ ). Stock solutions of seawater laced with ${ }^{13} \mathrm{C}$ and ${ }^{15} \mathrm{~N}$ were made by dissolving $\mathrm{NaH}^{13} \mathrm{CO}_{3}$ and $\mathrm{Na}^{15} \mathrm{NO}_{3}$ into filtered and autoclaved seawater. Aliquots of this enriched seawater were added to each culture $24 \mathrm{~h}$ prior to the start of the experiment to reach the final concentrations $\left(\mathrm{NaH}^{13} \mathrm{CO}_{3}(1.18 \mathrm{mM})\right.$ and $\mathrm{Na}^{15} \mathrm{NO}_{3}$ $(0.117 \mathrm{mM}))$ according to methods outlined in Freeman et al. (2013). Dual labels (both ${ }^{13} \mathrm{C}$ and ${ }^{15} \mathrm{~N}$ ) were used to ensure that cells were adequately enriched in at least one isotope to allow for evidence of trophic transfer $\left({ }^{13} \mathrm{C}\right.$ and/or ${ }^{15} \mathrm{~N}$ enrichment in bivalve tissue). Although we used inorganic tracers to enrich microalgae in both ${ }^{15} \mathrm{~N}$ and ${ }^{13} \mathrm{C}$, because the labeling of bivalve tissue in ${ }^{13} \mathrm{C}$ was minimal, the results focus solely on $\delta^{15} \mathrm{~N}$ values.

After feeding assays, dried whole bivalve soft tissue was ground to a fine powder using a mortar and pestle. Bivalve tissue was acidified by exposure to $12 \mathrm{~N} \mathrm{HCl}$ fumes in a closed environment for $12 \mathrm{~h}$. After drying at $60{ }^{\circ} \mathrm{C}$ to remove residual acid, samples were weighed to the nearest $0.001 \mathrm{mg}$ into tared tin capsules. Isotope analysis was carried out at the 
Stable Isotope Facility at UC Davis using a PDZ Europa ANCA-GSL elemental analyzer interfaced to a PDZ Europa 20-20 isotope ratio mass spectrometer (Sercon Ltd., Cheshire, UK). Isotope values are reported in $\delta$ notation in units of permil (\%o) (Fry 2006).

\section{Statistics}

Clearance rates were compared using a two-way repeated measures ANOVA with bivalve species and microalgal species as fixed factors and day as the repeated measure. Individuals that did not eat (no change in algal concentration) were excluded from analysis. Therefore, trials were repeated over the course of summer 2015 to achieve $n=5$ for each species with each algal type, except mussels $P$. viridis with A. lagunensis; exposure could not be done for this combination because there were no mussels to do the exposure. To determine patterns masked by interactions, repeated measures ANOVAs were performed for each bivalve species using algae as a fixed factor and day as the repeated measure. Further interactions were explored using one-way ANOVAs for each bivalve species and day. Bonferroni correction and Tukey's post hoc test were used to determine differences within factors. Data was log transformed to meet assumptions for analysis using ANOVA.

To elucidate if the bivalves were isotopically enriched, a blocked ANOVA was used to compare the $\delta^{15} \mathrm{~N}$ values of the bivalves in the laboratory against the natural abundance (unmanipulated, wild-caught bivalves) isotope values of three bivalves collected in the IRL (C. virginica, M. mercenaria, and the ribbed mussel Geukensia demissa). Enrichment source (laboratory or wild) was used as a main effect while bivalve species was used as a block to account for multiple species being combined in the analysis.

\section{Results}

\section{Microalgae Identifications}

Genbank searches allowed generic identification for two of the microalgae (CYAN1 and CHLO1), while the third (CYAN2) could only be resolved at the family level and given temporary generic assignment. The picocyanobacterium (CYAN1) was resolved as a Crocosphaera sp. (Aphanothecaceae, Chroococales) because it was nested among other representative species of this recently described genus (Mares et al. 2019), which received high support (96\%) in our $16 \mathrm{~S}$ phylogeny (Fig. 1a). The second picocyanobacterium (CYAN2) clustered within the family Prochlorotrichaceae (Synechococcales) described by BurgerWiersma et al. (1989) and supported in recent revision of sister families (Mai et al. 2018). Our sequence is nested in a clade of environmental sequences, which receives overall low support (48\%) and to date has no formal generic recognition (Fig. 1b). However, since unicellular taxa in the order Synechococcales (e.g., Uyeda et al. 2016), including within the family Prochlorotrichaceae (Akagha et al. 2019), are polyphyletic and generally referred to the form genus 'Synechococcus', this epithet can be assigned temporarily. Lastly, the picochlorophyte CHLO1 corresponded to Picochlorum sp. (Chlorellaceae incertae cedis, Chlorellales), which belong to class Trebouxiophyceae rather than the Pedinophyceae (a previous tentative identification, Phlips et al. 2015). CHLO1 is nested among a clade of Picochlorum spp. (sensu Henley et al. 2004) that includes cultured strains and others published from environmental sequencing (Fig. 1c). The broad Picochlorum spp. clade receives high support (92\%), but the backbone uniting taxa of the family Chlorellaceae (e.g., Marvania and polyphyletic Chlorella spp.) is unresolved (i.e., low bootstrap). The backbones of the family Aphanothecaceae and Prochlorotrichaceae are likewise poorly resolved with $16 \mathrm{~S}$.

\section{Clearance Rates}

Interactions were significant among bivalves, algae, and day (bivalves $\times$ algae: $F_{19,114}=2.943, p<0.001$; bivalves $\times$ day: $F_{5,114}=6.227, p<0.001$, algae $\times$ day: $F_{4,114}=2.75, p=$ 0.032 , bivalves $\times$ algae $\times$ day: $\left.F_{19}, 114=3.753, p<0.001\right)$. To elucidate differences masked by the interactions the following tests were performed:

\section{CR Results by Bivalve Species}

Differences were observed for each species of bivalve feeding on the microalgae species for both time points. There was not a common trend, and bivalves responded differently to the feeding exposures with high variances among clearance rates within and between bivalve species (Table 1). A two-way repeated measures ANOVA showed that $C$. virginica fed differently on the different algal species $\left(F_{4,19}=8.503 ; p<0.001\right.$, Fig. 2$)$. For example, $C$. virginica clearance rates of A. lagunensis ranged from 1 to $3 \mathrm{~L} \mathrm{~h}^{-1}$, while clearance of Picochlorum sp. ranged from $0.05-2.6 \mathrm{~L} \mathrm{~h}^{-1}$. Length of exposure differentially affected clearance, but high variation prevented any clear patterns from emerging (day: $F_{1,19}=0.532, p=0.475$; algae $\times$ day: $F_{4,19}=2.791, p=0.056$, Fig. 2). Rangia cuneata had consistently low clearance rates of $0.1 \mathrm{~L} \mathrm{~h}^{-1}$ on Synechococcus sp., but much higher rates of $2.56 \mathrm{~L} \mathrm{~h}^{-1}$ on A. lagunensis. However, clearance rates for the various algae did not differ, nor did length of exposure affect clearance rates (algae: $F_{4,20}=1.782, p=$ 0.172; day: $F_{1,20}=2.008, p=0.172$; algae $\times$ day: $F_{4,20}=$ 
Table 1 Average clearance rates $\left(\mathrm{L} \mathrm{h}^{-1} \pm \mathrm{SE}\right)$ for each bivalve species feeding on the different microalgae on days 0 and 4 of the experiment

\section{A. lagunensis}

$2.17 \pm 1.16$

$1.60 \pm 0.42$

Day 4

Mercenaria mercenaria

$\begin{array}{ll}\text { Day 0 } & 2.28 \pm 0.66 \\ \text { Day } 4 & 0.41 \pm 0.43\end{array}$

Rangia cuneata

$\begin{array}{ll}\text { Day 0 } & 1.54 \pm 1.02 \\ \text { Day } 4 & 0.79 \pm 0.84\end{array}$

Ischadium recurvum

$\begin{array}{ll}\text { Day 0 } & 0.53 \pm 0.22 \\ \text { Day } 4 & 2.04 \pm 0.64\end{array}$

Perna viridis

Day 0

Day 4

Mytella charruana

\begin{tabular}{llllll} 
Day 0 & $3.29 \pm 1.38$ & $2.91 \pm 1.65$ & $4.07 \pm 2.60$ & $1.51 \pm 1.01$ & $2.91 \pm 1.53$ \\
Day 4 & $4.35 \pm 2.16$ & $4.20 \pm 1.30$ & $1.59 \pm 1.47$ & $0.40 \pm 0.13$ & $4.47 \pm 1.60$ \\
\hline
\end{tabular}

1.448, $p=0.255$, Fig. 2). Length of exposure altered clearance depending on the algal species for all other species (algae $\times$ day: I. recurvum: $F_{4,20}=12.107, p<0.001$;
M. mercenaria: $F_{4,20}=4.145, p=0.001 ; M$. charruana: $F_{4,19}=5.352, p=0.005 ; P$. viridis: $F_{3,16}=5.665, p=$ 0.008 , Fig. 2).
Fig. 2 Clearance rates for each bivalve species (mean $\pm \mathrm{SE}$ ).

Black bars are clearance rates on Day 0; white bars are clearance rates on Day 4

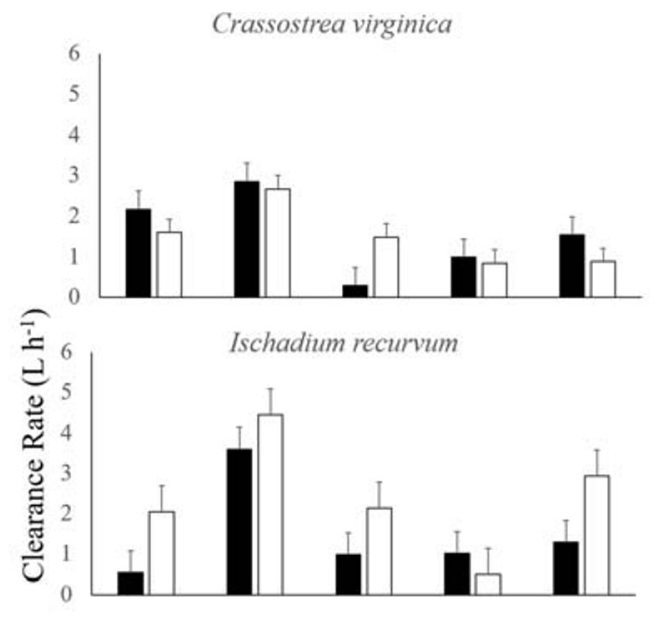

Mytella charruana

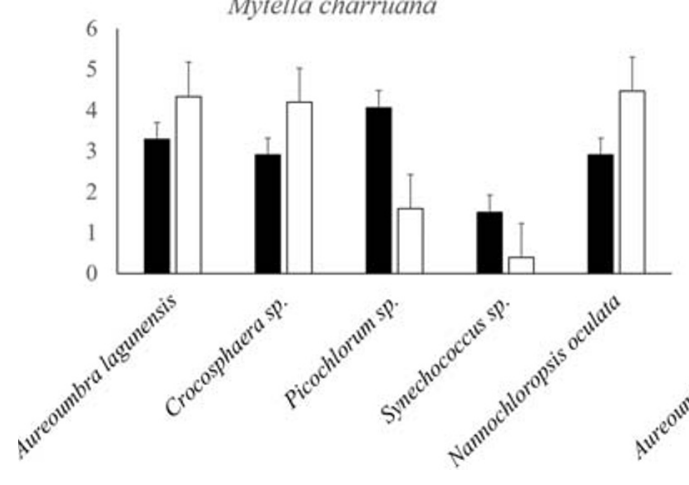

$$
0.99 \pm 0.55
$$$$
0.84 \pm 0.45
$$

$1.53 \pm 0.64$

$0.88 \pm 0.27$

$$
0.21 \pm 0.07
$$

$0.46 \pm 0.39$

$1.47 \pm 0.75$

$1.35 \pm 1.72$

$0.55 \pm 0.26$

$1.16 \pm 0.75$

$1.28 \pm 1.20$

$2.93 \pm 0.66$

$1.09 \pm 0.65$

$1.01 \pm 0.67$

$0.29 \pm 0.08$

Rangia cuneata

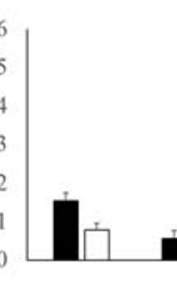

Mercenaria mercenaria
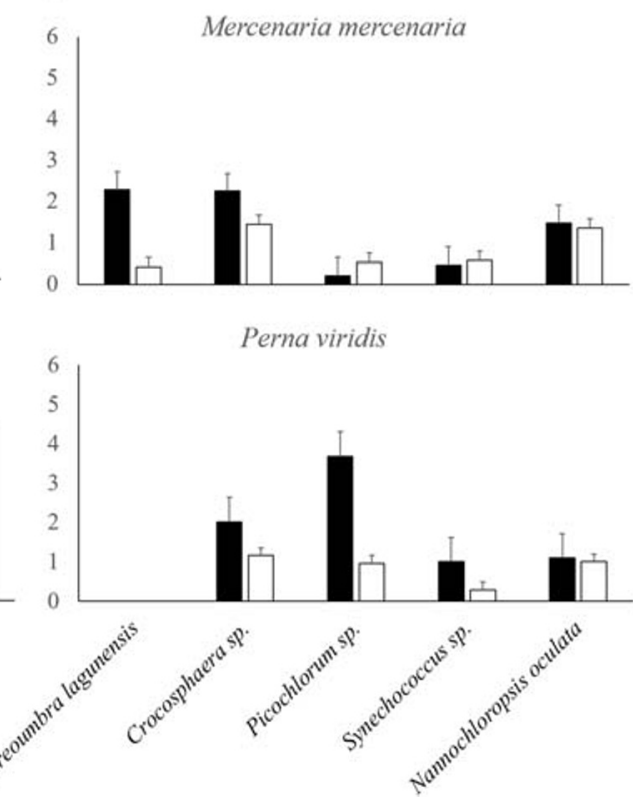

Perna viridis

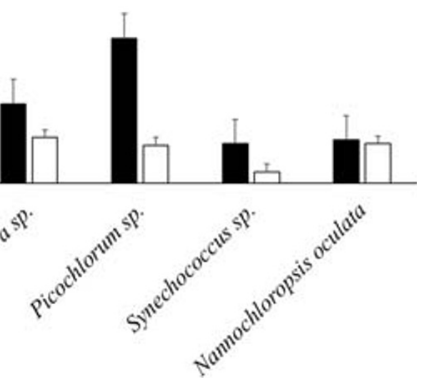




\section{CR Results Comparing Sampling Days}

ANOVA comparing day 0 and day 4 elucidated the differences between time points for those bivalves that altered feeding with length of exposure (all bivalves except $C$. virginica and $R$. cuneata). Ischadium recurvum increased clearance rate of Aureoumbra over the course of the experiment from $0.53 \pm$ 0.22 to $2.04 \pm 0.64 \mathrm{~L} \mathrm{~h}^{-1}$ (Aureoumbra: $F_{1,4}=35.000, p=$ $0.004)$ but did not alter their feeding on the other species (Nannochloropsis: $F_{1,4}=6.634, p=0.062$, Crocosphaera: $F_{1,4}=1.399, p=0.302$, Picochlorum: $F_{1,4}=3.963, p=$ 0.117, 'Synechococcus': $F_{1,4}=6.232, p=0.067$; Table 2; Fig. 2). Mercenaria mercenaria decreased clearance of Aureoumbra over the course of the experiment, from $2.28 \pm$ 0.66 to $0.41 \pm 0.43 \mathrm{~L} \mathrm{~h}^{-1}$ (Aureoumbra: $F_{1,4}=29.561, p=$ 0.006 ), but did not alter feeding on the other algae species (Nannochloropsis: $F_{1,4}=1.608, p=0.274$, Crocosphaera: $F_{1,4}=2.528, p=0.187$, Picochlorum: $F_{1,4}=1.55, p=$ 0.281, 'Synechococcus': $F_{1,4}=0.223, p=0.661$; Table 2; Fig. 2). Perna viridis decreased clearance of Picochlorum and 'Synechococcus' over the course of the experiment, from $3.68 \pm 0.49$ to $0.96 \pm 0.5 \mathrm{~L} \mathrm{~h}^{-1}$ and $1.00 \pm 0.41$ to $0.29 \pm$ $0.08 \mathrm{~L} \mathrm{~h}^{-1}$, respectively (Picochlorum: $F_{1,4}=21.241, p=$ 0.010, 'Synechococcus': $F_{1,4}=62.192, p=0.001$ ) but did not alter feeding on the other algae species (Nannochloropsis: $F_{1,4}=0.772, p=0.429$, Crocosphaera:

Table 2 ANOVA tables for one-way ANOVAs comparing day 0 with day 4

\begin{tabular}{|c|c|c|c|}
\hline Bivalve species & Algae species & $F_{1,4}$ value & $p$ value \\
\hline \multirow[t]{5}{*}{ Ischadium recurvum } & Aureoumbra lagunensis & 35.00 & $0.004 *$ \\
\hline & Picochlorum sp. & 1.40 & 0.302 \\
\hline & Crocosphaera sp. & 3.96 & 0.117 \\
\hline & Synechococcus sp. & 6.23 & 0.067 \\
\hline & Nannochloropsis oculata & 6.63 & 0.062 \\
\hline \multirow[t]{5}{*}{ Mercenaria mercenaria } & Aureoumbra lagunensis & 29.56 & $0.006^{*}$ \\
\hline & Picochlorum sp. & 2.53 & 0.187 \\
\hline & Crocosphaera sp. & 1.55 & 0.281 \\
\hline & Synechococcus sp. & 0.22 & 0.661 \\
\hline & Nannochloropsis oculata & 1.61 & 0.274 \\
\hline \multirow[t]{5}{*}{ Mytella charruana } & Aureoumbra lagunensis & 4.04 & 0.115 \\
\hline & Picochlorum sp. & 3.42 & 0.138 \\
\hline & Crocosphaera sp. & 4.60 & 0.098 \\
\hline & Synechococcus sp. & 6.33 & 0.086 \\
\hline & Nannochloropsis oculata & 2.42 & 0.195 \\
\hline \multirow[t]{5}{*}{ Perna viridis } & Aureoumbra lagunensis & - & - \\
\hline & Picochlorum sp. & 4.99 & 0.089 \\
\hline & Crocosphaera sp. & 21.24 & $0.010^{*}$ \\
\hline & Synechococcus sp. & 62.19 & $0.001 *$ \\
\hline & Nannochloropsis oculata & 0.77 & 0.429 \\
\hline
\end{tabular}

*Significant differences
$F_{1,4}=4.99, p=0.089$; Table 2; Fig. 2). Mytella charruana did not alter feeding over the course of the experiment (Aureoumbra: $F_{1,4}=4.042, p=0.115$, Nannochloropsis: $F_{1}$, ${ }_{4}=2.415, p=0.195$, Crocosphaera: $F_{1,4}=3.418, p=0.138$, Picochlorum: $F_{1,4}=4.604, p=0.098$, 'Synechococcus': $F_{1}$, ${ }_{4}=6.333, p=0.086$; Table 2; Fig. 2).

\section{CR Results Comparing Microalgae Species on each Day}

ANOVA comparing clearance rates for the different algae species elucidated the differences within each bivalve species that altered feeding with length of exposure (all bivalves except $C$. virginica and $R$. cuneata). Ischadium recurvum cleared $0.53 \pm 0.22 \mathrm{~L} \mathrm{~h}^{-1}$ of Aureoumbra and $1.28 \pm 1.20 \mathrm{~L} \mathrm{~h}^{-1}$ of Nannochloropsis, lower values than when feeding on Crocosphaera $\left(3.59 \pm 1.6 \mathrm{~L} \mathrm{~h}^{-1}\right)$ at first exposure, though they cleared less 'Synechococcus' $\left(0.49 \pm 0.35 \mathrm{~L} \mathrm{~h}^{-1}\right)$ than the other species after 4 days (Aureoumbra, $2.04 \pm 0.64 \mathrm{~L} \mathrm{~h}^{-1}$; Crocosphaera, $4.45 \pm 1.39 \mathrm{~L} \mathrm{~h}^{-1}$; Picochlorum, $2.13 \pm$ $1.02 \mathrm{~L} \mathrm{~h}^{-1}$; and Nannochloropsis, $2.93 \pm 0.66 \mathrm{~L} \mathrm{~h}^{-1}$ ) (day 0: $F_{4,25}=4.704, p=0.008$; day $4, F_{4,25}=20.426, p<0.001$, Fig. 2). Mercenaria mercenaria fed $0.46 \pm 0.39 \mathrm{~L} \mathrm{~h}^{-1}$ on 'Synechococcus' and $0.21 \pm 0.07 \mathrm{~L} \mathrm{~h}^{-1}$ on Picochlorum, lower values than the other algae species at first exposure but not after 4 days (day 0: $F_{4,25}=19.092, p=0.000$; day $4: F_{4,25}=$ $1.4, p=0.27$, Fig. 2). Perna viridis cleared more Picochlorum than the other three species after first exposure (3.68 \pm $0.49 \mathrm{~L} \mathrm{~h}^{-1}$ compared with $2.02 \pm 0.15,1.00 \pm 0.41$, and 1.09 $\pm 0.65 \mathrm{~L} \mathrm{~h}^{-1}$ from Crocosphaera, 'Synechococcus', and Nannochloropsis, respectively) but not on day 4 (day $0: F_{3}$, ${ }_{20}=7.944, p=0.002$; day 4: $F_{3,20}=3.108, p=0.056$, Fig. 2 ). Mytella charruana had lower clearance rates when fed 'Synechococcus' ( $\left.0.40 \pm 0.13 \mathrm{~L} \mathrm{~h}^{-1}\right)$ and Picochlorum (1.59 $\pm 1.47 \mathrm{~L} \mathrm{~h}^{-1}$ ) than the other three species (Aureoumbra, 4.35 $\pm 2.16 \mathrm{~L} \mathrm{~h}^{-1}$; Crocosphaera, $4.20 \pm 1.30 \mathrm{~L} \mathrm{~h}^{-1}$; and Nannochloropsis, $4.47 \pm 1.60 \mathrm{~L} \mathrm{~h}^{-1}$ ) but only after 4 days of exposure (day 0: $F_{4,24}=1.158, p=0.360$; day $4: F_{4,24}=$ 13.027, $p<0.001$, Fig. 2).

Summarily, bivalve feeding responses differed among species. The three species of mussels had the highest clearance rates, while $R$. cuneata had the lowest. Length of exposure was rarely important, though $I$. recurvum increased clearance of Aureoumbra while M. mercenaria decreased it. Average clearance rates were lowest on 'Synechococcus' (0.68 \pm $0.35 \mathrm{~L} \mathrm{~h}^{-1}$ ) across bivalve species (Aureoumbra, $1.90 \pm$ $0.89 \mathrm{~L} \mathrm{~h}^{-1}$; Crocosphaera, $2.55 \pm 0.99 \mathrm{~L} \mathrm{~h}^{-1}$; Picochlorum, $1.27 \pm 0.77 \mathrm{~L} \mathrm{~h}^{-1}$; and Nannochloropsis, $1.85 \pm 0.89 \mathrm{~L} \mathrm{~h}^{-1}$ ). While there was no single algal species that was cleared at high rates by all bivalves, Crocosphaera tended to be cleared by most bivalves, and Aureoumbra and Nannochloropsis had intermediate clearance rates. 


\section{Isotope Analyses}

Experimental bivalves were enriched in ${ }^{15} \mathrm{~N}$, with $\delta^{15} \mathrm{~N}$ values ranging from $\sim 10$ to over $100 \%$, while mean natural abundance $\delta^{15} \mathrm{~N}$ values of bivalves from the IRL was $6.7 \%$ (Fig. 3). This enrichment was significant, with bivalves fed the isotopically labeled microalgae having much higher $\delta^{15} \mathrm{~N}$ values than non-manipulated bivalves that had been feeding on natural suspended organic matter within Indian River Lagoon $\left(F_{1,250}=14.313, p<0.001\right)$.

\section{Discussion}

Our results point to an important connection between biodiversity and ecosystem services, with bivalve filter feeding potentially controlling microalgal bloom-forming species via top-down control. To restore water quality in eutrophic ecosystems and prevent algal bloom formation, several management practices may be implemented, including upgraded sewage treatment plants or best management agricultural practices (Whitall et al. 2007; Duarte et al. 2009; McCrackin et al. 2017). However, when excess nutrients accumulate in an estuary, filter-feeding organisms such as bivalves become key elements to restore the loss of the ecosystem functionality (Lucas et al. 1999; Newell 2004; Rose et al. 2014). Our findings suggest that resident bivalves may clear and assimilate bloom-forming microalgae originating from the IRL. All bivalves demonstrated enriched ${ }^{15} \delta$ values demonstrating that bivalves were assimilating algal-derived nutrients and not simply clearing cells from the water column. This finding has interesting implications as previous research indicated
A. lagunensis does not efficiently take up nitrate (DeYoe and Suttle 1994). The bivalves in this study cleared all species of microalgae and were greatly enriched in nitrogen, though the reason for the difference is unclear. Regardless, bivalvespecific responses to microalgal assemblages may affect the efficacy of mitigation, emphasizing that bivalve biodiversity is important for restoration purposes.

Here, thanks to cultures established at the onset of the 2011 bloom event, we were able to resolve the molecular identity and taxonomic assignment (down to the genus level, one provisional) of some of the taxa involved in past IRL bloom event. Future sequencing (e.g., genome/transcriptome) and morphological investigations of the two presently identified Cyanophyceae, Crocosphaera sp., and 'Synechococcus' sp., and the Trebouxiophyceae, Picochlorum sp., may allow further taxonomic resolution and eventual species description. Interestingly, the Crocosphaera sp. and Picochlorum sp. belong to orders whose representatives are primarily unicellular, but our 'Synechococcus' sp. is nested in the family Prochlorotrichaceae, which also harbors both filamentous and unicellular taxa (e.g., see phylogenetically interspersed Synechoccus sp. in Akagha et al. 2019). Overall, our generated DNA barcodes represent important genetic resources to facilitate the detection and tracking of these species in future environmental assays toward understanding the ecology and dynamic of microalgal blooms and blooms in the IRL. These generic epithets will also provide for more effective communication among local stakeholders.

The Indian River Lagoon remains at risk of intense algal blooms because of nutrient enrichment from point and nonpoint sources enhanced by human activities (Steward and Green 2007; Lapointe et al. 2015; Phlips et al. 2015; Barile

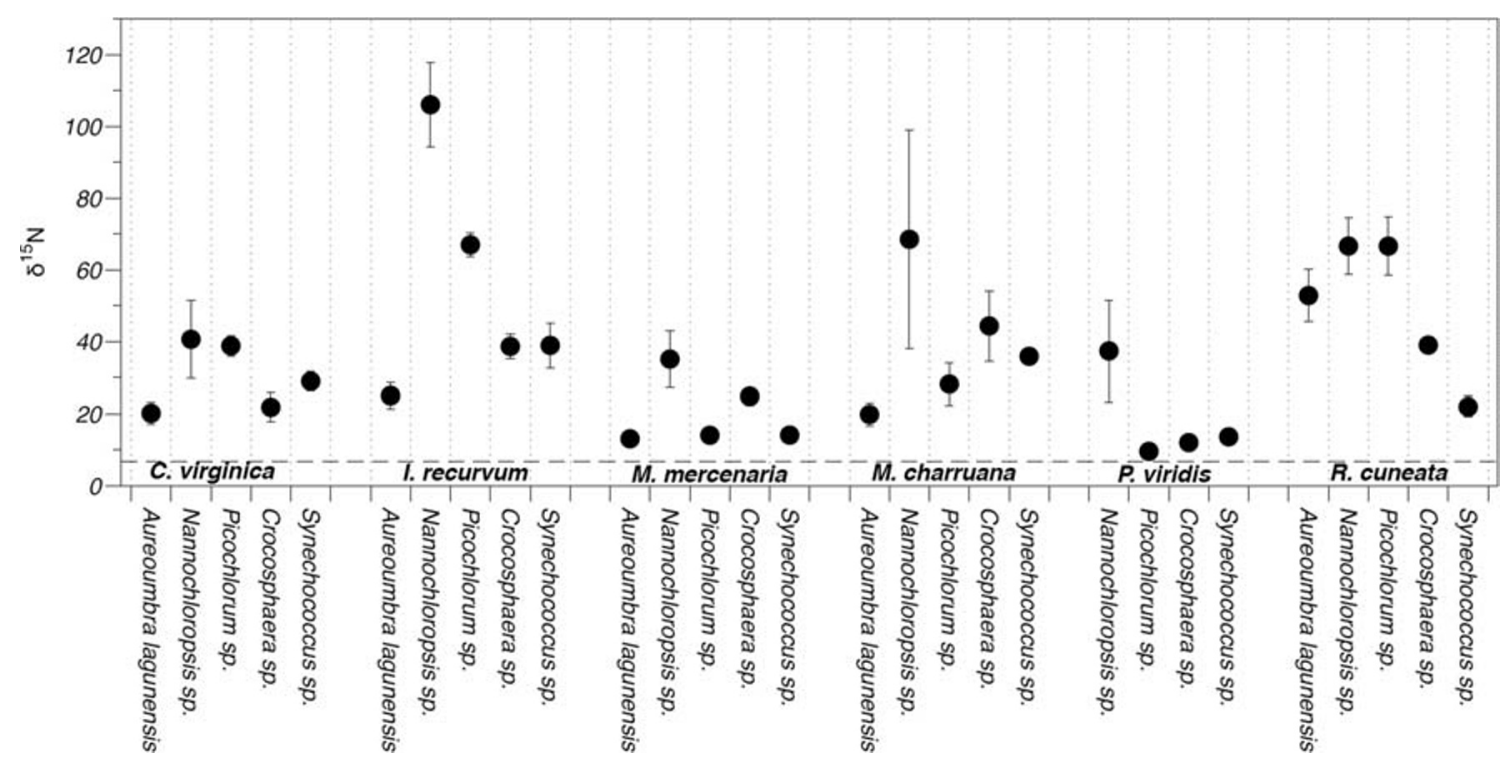

Fig. 3 Graph of experimental enrichment of nitrogen isotope values $\left(\delta^{15} \mathrm{~N}\right)$ for each bivalve species. The dotted line represents natural abundance $\delta^{15} \mathrm{~N}$ value for three species of bivalves (eastern oyster
Crassostrea virginica, ribbed mussel Geukensia demissa, and hard clam Mercenaria mercenaria) collected in the Indian River Lagoon 
2018). The mechanisms leading to the blooms may include multiple triggers including salinity and temperature, thus climate change might exacerbate microalgal proliferation in eutrophic ecosystems (Paerl and Paul 2012; Phlips et al. 2012, 2020). Declining populations of benthic filter-feeding macroinvertebrates (e.g., clams and oysters) in the IRL may have contributed to the potential formation of blooms. Restoration of bivalve populations may play a role in reestablishing ecosystem functions in the IRL that help limit future harmful algal blooms through top-down controls, as found in other estuaries (Lucas et al. 1999; Badylak and Phlips 2004). Understanding the role of specific bivalves is imperative to ensure restoration efforts are sustainable and successful. Our results demonstrate that $C$. virginica assimilated algal cells, did not alter their feeding behavior after continued exposure to the different tested microalgae and ingested the algal species at similar rates. Since this species is commonly distributed in the IRL and continuously clears large volumes of water, it may be a good candidate to help restore water quality in the estuary (Galimany et al. 2017b). Mytella charruana also maintained feeding on the different algal species with continued exposure. However, as a non-native species using it for restoration must be carefully considered. Conversely, clearance rates of $R$. cuneata were lower than those of the other bivalves, though the rates observed $\left(0.17-1.5 \mathrm{~L} \mathrm{~h}^{-1}\right)$ are similar to those reported previously (0.38-0.72 $\mathrm{L} \mathrm{h}^{-1}$ ) (Hartwell et al. 1991). Additionally, its ecology and possible preference for lower salinity may constrain the use of $R$. cuneata for restoration in the IRL. Indeed, while $R$. cuneata has been documented in salinities up to $38 \mathrm{ppt}$ (Anderson and Bedford 1973; Hopkins et al. 1973), it is generally confined to salinities lower than 15 ppt (Cooper 1981). Moreover, spawning only occurs at salinities below $15 \mathrm{ppt}$, and larval survival decreases at salinities above 10 ppt (Cain 1973; Hopkins et al. 1973). It is also possible that competition and predation constrain $R$. cuneata populations to lower salinity environments. These constraints may mean that the species is not naturally exposed to the microalgae tested in this study and may not thrive over the spatial range necessary for mitigation of the blooms in the IRL.

Among the different species that formed the superbloom, clearance rates of CYAN2 (i.e., 'Synechococcus' sp.) were lowest across bivalves and may indicate its lower ingestion. For instance, blooms of Synechococcus spp. in Florida Bay (which may or may not be related to the taxon sequenced herein since the genus is polyphyletic, e.g., Uyeda et al. 2016) were linked temporally with sponge mortality events (Butler et al. 1995), though sponges cleared the algae with no impairment (Lynch and Phlips 2000). It was therefore hypothesized that certain Synechococcus strains may produce toxins under stress or impair filtration by excreting a carbohydrate polymer (Lynch and Phlips 2000). Bivalves are active filter feeders able to select the particles to ingest based on several particle characteristics. Because of the structure of the gills, particle size plays an important role to be retained in gills, and particles as small as $1 \mu \mathrm{m}$ may be efficiently retained for a great variety of bivalves (Møhlenberg and Riisgård 1978). Our 'Synechococcus' sp. was large enough to be efficiently retained in the gills $(5.74 \pm 07 \mu \mathrm{m}$ in diameter), and the stable isotope results demonstrate that it was ingested and assimilated by the bivalves. Therefore, the low clearance rates indicate that other particle properties such as physical or chemical surface properties of this cyanobacterium may determine its low preference by the bivalves (Rosa et al. 2017). For example, a surface protein in a Synechococcus strain known as WH8102 has been demonstrated to deter feeding on some dinoflagellates (Strom et al. 2012). Further research needs to be conducted on our 'Synechococcus' strain CYAN2 to determine the origin of its putative harmful effects.

Brown tides caused by Aureoumbra lagunensis may persist within coastal ecosystems long after they are first observed. For example, a brown tide event in the Laguna Madre, TX persisted for over 8 years (Buskey et al. 1998). In the Indian River Lagoon, FL, brown tide was reported in 2012 (Gobler et al. 2013; Phlips and Badylak 2013; Phlips et al. 2015), reappeared in 2013, 2015, 2016, and 2018 (Galimany et al. 2017b; Phlips et al. 2019). Therefore, preventing brown tide formation is exceptionally important, and our study indicates that restoration efforts with bivalves may mediate the spread of this bloom species. In particular, I. recurvum and species with similar physiologies might be an ideal candidate for restoring water quality in areas where A. lagunensis blooms are frequent as I. recurvum increased its feeding on A. lagunensis over the course of the experiment. This is especially promising as, based on the isotope data, the bivalves did consume and assimilate the algal cells rather than simply clear them. However, within the IRL, the brown tide is most prevalent in the Banana River while I. recurvum is most abundant in the brackish tributaries of the IRL (e.g., St. Lucie River). This distribution difference might be explained by their salinity tolerances. Aureoumbra lagunensis has a wide salinity range (10-90 psu) (Buskey et al. 1998). Ischadium recurvum is also tolerant of a wide salinity range, and has been reported in the field at salinities of 2.5-40 ppt (Parker 1959; Allen 1960; Castagna and Chanley 1973). However, I. recurvum preferred lower salinities when feeding behavior was tested across a salinity gradient (8-32 ppt) (Galimany et al. 2018). These differences in habitat preference could limit $I$. recurvum from being an effective tool in bloom mitigation. Under this scenario, $C$. virginica might be a better candidate to prevent brown tides because the clearance rate was sustained at about $2 \mathrm{~L} \mathrm{~h}^{-1}$, and $\delta^{15} \mathrm{~N}$ values of $C$. virginica tissue suggest that this species is able to assimilate nitrogen from A. lagunensis. Conversely, $M$. mercenaria decreased feeding on $A$. lagunensis over the course of the experiment. This is not surprising as these bivalves have relatively low clearance rates 
and are least successful in water conditions with high seston loads as they do not sort particles well (Bricelj and Malouf 1984; Galimany et al. 2017b; Galimany et al. 2018). Aureoumbra lagunensis is known to secrete an exopolymeric substance (Buskey et al. 1998; Liu and Buskey 2000) and may have been the most difficult species for M. mercenaria to clear. Therefore, several factors apart from the feeding behavior of bivalves, i.e., salinity tolerance, must be considered when restoring grazers to ameliorate algal blooms.

Bivalve species that establish and become invasive in new environments may have broader adaptability or higher efficiencies than native species, including higher resistance to pathogens (Wendling and Wegner 2015), higher growth and reproductive output (Branch and Steffani 2004), and higher clearance rates (Sousa et al. 2009; Galimany et al. 2017a). In the IRL, populations of invasive bivalves include the mussels $M$. charruana and $P$. viridis. Previous research has documented that M. charruana has high clearance rates clearing even more microalgae than $C$. virginica (Galimany et al. 2017a), as found in the present study. Perna viridis may have similar clearance rates as $M$. charruana when feeding on natural seston and can circulate volumes of water as high as $3 \mathrm{~L} \mathrm{~h}^{-1}$ (Galimany et al. 2018). In this study, P. viridis altered its feeding over the course of the experiment, as did $M$. charruana. However, while $P$. viridis decreased its feeding with exposure, the feeding responses varied for $M$. charruana indicating that it might preferably feed on different microalgae. Perna viridis is most commonly found within the inlets of the northern IRL, which may limit the exposure of the species to the harmful algae tested. Both M. charruana and $P$. viridis, as non-native species, are not encouraged to use for restoration regardless of the potential benefits to prevent ecosystem impairment as observed in other invaded areas (Karatayev et al. 1997; Ricciardi et al. 1998).

Bivalve species differ in responses when grazing on phytoplankton populations (Kiørboe and Møhlenberg 1981; Hégaret et al. 2007). Studying these relationships is essential to understand potential top down control of microalgae by bivalves. All species were tested at a pre-bloom concentration $\left(3 \times 10^{4}\right.$ cells $\left.\mathrm{mL}^{-1}\right)$, and the feeding behaviors of bivalve species could be different at greater concentrations. In fact, clearance rates are likely to decrease with increasing concentrations as the bivalves must circulate more material through their gills (Montagna et al. 1993; Bacon et al. 1998). Importantly, our results indicate that no single species can do it all, and diverse assemblages of filter feeders may amplify the ecosystem services provided by these organisms in estuarine systems. Additional work is needed to investigate the role of other epifaunal and benthic filter feeders that are currently dominant members of these communities within the IRL (Freeman et al. 2018; Janiak et al. 2018). Our results indicate that bloom-forming algal species in the IRL can be cleared and assimilated by resident bivalves and that restoring healthy populations of native filter feeding species may aid in the mitigation or prevention of harmful algae blooms in coastal waters. This information is needed for the restoration community and stakeholders to better manage the estuary using the bivalve species that best fit with algal bloom prevention strategies.

Acknowledgments We thank Smithsonian Marine Station staff for providing logistical support. This is Smithsonian Marine Station contribution \#1138.

Funding Information We thank St. Johns River Water Management District (Contract 27799) and the Florida Fish and Wildlife Conservation Commission (FWC Agreement No. 13051) for funding the project.

Open Access This article is licensed under a Creative Commons Attribution 4.0 International License, which permits use, sharing, adaptation, distribution and reproduction in any medium or format, as long as you give appropriate credit to the original author(s) and the source, provide a link to the Creative Commons licence, and indicate if changes were made. The images or other third party material in this article are included in the article's Creative Commons licence, unless indicated otherwise in a credit line to the material. If material is not included in the article's Creative Commons licence and your intended use is not permitted by statutory regulation or exceeds the permitted use, you will need to obtain permission directly from the copyright holder. To view a copy of this licence, visit http://creativecommons.org/licenses/by/4.0/.

\section{References}

Adams, D.H., D.M. Tremain, R. Paperno, and C. Sonne. 2019. Florida lagoon at risk of ecosystem collapse. Science 365 (6457): 991-992.

Akagha, S.C., J.R. Johansen, D.I. Nwankwo, and K. Yin. 2019. Lagosinema tenuis gen. et sp. nov. (Prochlorotrichaceae, Cyanobacteria): A new brackish water genus from Tropical Africa. Fottea 19 (1): 1-12.

Allen, J. 1960. Effect of low salinity on survival of the curved mussel, Brachiodontes recurvus. Nautilus 74: 1-8.

Altschul, S.F., T.L. Madden, A.A. Schäffer, J. Zhang, Z. Zhang, W. Miller, and D.J. Lipman. 1997. Gapped BLAST and PSI-BLAST: A new generation of protein database search programs. Nucleic Acids Research 25 (17): 3389-3402.

Anderson, J.W., and W.B. Bedford. 1973. The physiological response of the estuarine clam, Rangia cuneata (Gray), to salinity. II. Uptake of glycine. The Biological Bulletin 144 (2): 229-247.

Arnold, W.S. 2001. Bivalve enhancement and restoration strategies in Florida, U.S.A. Hydrobiologia 465 (1/3): 7-19.

Bacon, G.E., B.A. MacDonald, and J.E. Ward. 1998. Physiological responses of infaunal (Mya arenaria) and epifaunal (Placopecten magellanicus) bivalves to variations in the concentration and quality of suspended particles: I. Feeding activity and selection. Journal of Experimental Marine Biology and Ecology 219 (1-2): 105-125.

Badylak, S., and E.J. Phlips. 2004. Spatial and temporal patterns of phytoplankton composition in a subtropical coastal lagoon, the Indian River Lagoon, Florida, USA. Journal of Plankton Research 26 (10): 1229-1247.

Barile, P.J. 2018. Widespread sewage pollution of the Indian River Lagoon system, Florida (USA) resolved by spatial analyses of macroalgal biogeochemistry. Marine Pollution Bulletin 128: $557-574$. 
Beck, M.W., R.D. Brumbaugh, L. Airoldi, A. Carranza, L.D. Coen, C. Crawford, O. Defeo, G.J. Edgar, B. Hancock, M.C. Kay, H.S. Lenihan, M.W. Luckenbach, C.L. Toropova, G. Zhang, and X. Guo. 2011. Oyster reefs at risk and recommendations for conservation, restoration, and management. BioScience 61 (2): 107-116.

Branch, G.M., and C.N. Steffani. 2004. Can we predict the effects of alien species? A case-history of the invasion of South Africa by Mytilus galloprovincialis (Lamarck). Journal of Experimental Marine Biology and Ecology 300 (1-2): 189-215.

Bricelj, V.M., and R.E. Malouf. 1984. Influence of algal and suspended sediment concentrations on the feeding physiology of the hard clam Mercenaria mercenaria. Marine Biology 84 (2): 155-165.

Bricker, S., and M. Devlin. 2011. Eutrophication - international comparisons of water quality challenges. Biogeochemistry 105: 135-302.

Bricker, S.B., B. Longstaff, W. Dennison, A. Jones, K. Boicourt, C. Wicks, and J. Woerner. 2008. Effects of nutrient enrichment in the nation's estuaries: A decade of change. Harmful Algae 8 (1): 21-32.

Burger-Wiersma, T., L.J. Stal, and L.R. Mur. 1989. Prochlorothrix hollandica gen. nov., sp. nov., a filamentous oxygenic photoautotrophic procaryote containing chlorophylls a and $\mathrm{b}$ : Assignment to Prochlorotrichaceae fam. nov. and order Prochorales Florenzano, Balloni, and Materassi 1986, with emend. International Journal of Systematic Bacteriology 39 (3): 250-257.

Buskey, E.J., B. Wysor, and C. Hyatt. 1998. The role of hypersalinity in the persistence of the Texas "brown tide" in the Laguna Madre. Journal of Plankton Research 20 (8): 1553-1565.

Buskey, E.J., H. Liu, C. Collumb, and J.G.F. Bersano. 2001. The decline and recovery of a persistent Texas brown tide algal bloom in the Laguna Madre (Texas, USA). Estuaries 24 (3): 337.

Butler, M.J., J.H. Hunt, W.F. Herrnkind, M.J. Childress, R. Bertelsen, W. Sharp, T. Matthews, J.M. Field, and H.G. Marshall. 1995. Cascading disturbances in Florida Bay, USA: Cyanobacteria blooms, sponge mortality, and implications for juvenile spiny lobsters Panulirus argus. Marine Ecology Progress Series 129: 119125.

Cain, T.D. 1973. The combined effects of temperature and salinity on embryos and larvae of the clam Rangia cuneata. Marine Biology 21 (1): $1-6$

Capriulo, G.M., G. Smith, R. Troy, G.H. Wikfors, J. Pellet, and C. Yarish. 2002. The planktonic food web structure of a temperate zone estuary, and its alteration due to eutrophication. Hydrobiologia 475476: 263-333.

Castagna, M., and P. Chanley. 1973. Salinity tolerance of some marine bivalves from inshore and estuarine environments in Virginia waters on the western Mid-Atlantic coast. Malacologia 12: 47-96.

Cooper, R. 1981. Salinity tolerance of Rangia cuneata (Pelecypoda: Mactridae) in relation to its estuarine environment: A review. Transactions of the Physiological, Oecological, Experimental Taxonomic and Systematics Society 1: 19-31.

Coughlan, J. 1969. The estimation of filtering rate from the clearance of suspensions. Marine Biology 2 (4): 356-358.

Dame, R.F. 1993. The role of bivalve filter feeder material fluxes in estuarine ecosystems. In Bivalve filter feeders, ed. R.F. Dame, 245-269. Berlin: Springer-Verlag.

DeYoe, H.R., and C.A. Suttle. 1994. The inability of the Texas brown tide alga to use nitrate and the role of nitrogen in the initiation of a persistent bloom of the organism. Journal of Phycology 30 (5): 800-806.

DeYoe, H.R., D.A. Stockwell, R.R. Bidigare, M. Latasa, P.W. Johnson, P.E. Hargraves, and C.A. Suttle. 1997. Description and characterization of the algal species Aureoumbra lagunensis gen. et sp. nov. and referral of Aureoumbra and Aureococcus to the Pelagophyceae. Journal of Phycology 33 (6): 1042-1048.

Duarte, C.M., D.J. Conley, J. Carstensen, and M. Sánchez-Camacho. 2009. Return to Neverland: Shifting baselines affect eutrophication restoration targets. Estuaries and Coasts 32 (1): 29-36.
Dybas, C.L. 2002. Florida's Indian River Lagoon: An estuary in transition. BioScience 52: 554-559.

Freeman, C.J., R.W. Thacker, D.M. Baker, and M.L. Fogel. 2013. Quality or quantity: Is nutrient transfer driven more by symbiont identity and productivity than by symbiont abundance? ISME Journal 7 (6): $1116-1125$.

Freeman, C.J., D.S. Janiak, M. Mossop, R. Osman, and V.J. Paul. 2018. Spatial and temporal shifts in the diet of the barnacle Amphibalanus eburneus within a subtropical estuary. PeerJ 6: e5485.

Fry, B. 2006. Stable isotope ecology. 3rd ed. New York: Springer-Verlag.

Galimany, E., C.J. Freeman, J. Lunt, A. Domingos, P. Sacks, and L. Walters. 2017a. Feeding competition between the native oyster Crassostrea virginica and the invasive mussel Mytella charruana. Marine Ecology Progress Series 564: 57-66.

Galimany, E., J. Lunt, C.J. Freeman, S. Reed, I. Segura-García, and V.J. Paul. 2017b. Feeding behavior of eastern oysters Crassostrea virginica and hard clams Mercenaria mercenaria in shallow estuaries. Marine Ecology Progress Series 567: 125-137.

Galimany, E., J. Lunt, A. Domingos, and V.J. Paul. 2018. Feeding behavior of the native mussel Ischadium recurvum and the invasive mussels Mytella charruana and Perna viridis in FL, USA, across a salinity gradient. Estuaries and Coasts 41 (8): 2378-2388.

Garvis, S.K., P.E. Sacks, and L.J. Walters. 2015. Formation, movement, and restoration of dead intertidal oyster reefs in Canaveral National Seashore and Mosquito Lagoon, Florida. Journal of Shellfish Research 34 (2): 251-258.

Gobler, C.J., F. Koch, Y. Kang, D.L. Berry, Y.Z. Tang, M. Lasi, L. Walters, L. Hall, and J.D. Miller. 2013. Expansion of harmful brown tides caused by the pelagophyte, Aureoumbra lagunensis DeYoe et Stockwell, to the US east coast. Harmful Algae 27: 29-41.

Gosling, E. 2003. Bivalve molluscs: Biology, ecology, and culture. Oxford (UK): Blackwell Publishing.

Halpern, B.S., K.A. Selkoe, F. Micheli, and C.V. Kappel. 2007. Evaluating and ranking the vulnerability of global marine ecosystems to anthropogenic threats. Conservation Biology 21 (5): 13011315 .

Hartwell, S., D. Wright, R. Takacs, and C. Hocutt. 1991. Relative respiration and feeding rates of oyster and brackish water clam in variously contaminated waters. Marine Pollution Bulletin 22 (4): 191-197.

Hégaret, H., G.H. Wikfors, and S.E. Shumway. 2007. Diverse feeding responses of five species of bivalve mollusc when exposed to three species of harmful algae. Journal of Shellfish Research 26 (2): 549-559.

Heisler, J., P. Glibert, J. Burkholder, D. Anderson, W. Cochlan, W. Dennison, C. Gobler, Q. Dortch, C. Heil, E. Humphries, A. Lewitus, R. Magnien, H. Marshall, K. Sellner, D. Stockwell, D. Stoecker, M. Suddleson, and B.W. Baruch. 2008. Eutrophication and harmful algal blooms: A scientific consensus. Harmful Algae 8 (1): 3-13.

Henley, W., J. Hironaka, L. Guillou, M. Buchheim, J. Buchheim, M. Fawley, and K. Fawley. 2004. Phylogenetic analysis of the 'Nannochloris-like' algae and diagnoses of Picochlorum oklahomensis gen. et sp. nov. (Trebouxiophyceae, Chlorophyta). Phycologia 43 (6): 641-652.

Hopkins, S.H., J. W. Anderson, and K. Horvath. 1973. The brackish water clam Rangia cuneata as indicator of ecological effects of salinity changes in coastal waters. Contract report H-73-1.

Janiak, D.S., R.W. Osman, C.J. Freeman, and V.J. Paul. 2018. Artificial structures versus mangrove prop roots: A general comparison of epifaunal communities within the Indian River Lagoon, Florida, USA. Marine Ecology Progress Series 607: 85-98.

Kahru, M., R. Elmgren, J. Kaiser, N. Wasmund, and O. Savchuk. 2020. Cyanobacterial blooms in the Baltic Sea: Correlations with environmental factors. Harmful Algae 92: 101739. 
Kamerosky, A., H.J. Cho, and L. Morris. 2015. Monitoring of the 2011 super algal bloom in Indian River Lagoon, FL, USA, using MERIS. Remote Sensing 7 (2): 1441-1460.

Karatayev, A.Y., E. Lyubov, and D.K. Padilla. 1997. The effects of Dreissena polymorpha (Pallas) invasion on aquatic communities in Eastern Europe. Journal of Shellfish Research 16: 187-203.

Kiørboe, T., and F. Møhlenberg. 1981. Particle selection in suspensionfeeding bivalves. Marine Ecology Progress Series 5: 291-296.

Landsberg, J.H. 2002. The effects of harmful algal blooms on aquatic organisms. Reviews in Fisheries Science 10 (2): 113-390.

Lapointe, B.E., L.W. Herren, D.D. Debortoli, and M.A. Vogel. 2015. Evidence of sewage-driven eutrophication and harmful algal blooms in Florida's Indian River Lagoon. Harmful Algae 43: 82-102.

Lapointe, B.E., L.W. Herren, R.A. Brewton, and P.K. Alderman. 2020. Nutrient over-enrichment and light limitation of seagrass communities in the Indian River Lagoon, an urbanized subtropical estuary. Science of the Total Environment 699: 134068.

Liu, H., and E.J. Buskey. 2000. Hypersalinity enhances the production of extracellular polymeric substance (EPS) in the Texas brown tide alga, Aureoumbra lagunensis (Pelagophyceae). Journal of Phycology 36 (1): 71-77.

Lucas, L.V., J.R. Koseff, J.E. Cloern, S.G. Monismith, and J.K. Thompson. 1999. Processes governing phytoplankton blooms in estuaries. I: The local production-loss balance. Marine Ecology Progress Series 187: 1-15.

Lynch, T.C., and E.J. Phlips. 2000. Filtration of the bloom-forming cyanobacteria Synechococcus by three sponge species from Florida Bay, U.S.A. Bulletin of Marine Science 67: 923-936.

MacKenzie, C.L., Jr., D.L. Taylor, and W.S. Arnold. 2001. A history of hard clamming. In Biology of the hard clam, ed. J. Kraeurer and M. Castagna, 651-671. Amsterdam: Elsevier.

Mai, T., J.R. Johansen, N. Pietrasiak, M. Bohunická, and M.P. Martin. 2018. Revision of the Synechococcales (Cyanobacteria) through recognition of four families including Oculatellaceae fam. nov. and Trichocoleaceae fam. nov. and six new genera containing 14 species. Phytotaxa 365 (1): 1-59.

Mares, J., J. Johansen, T. Hauer, J. Zima Jr., S. Ventura, O. Cuzman, B. Tiribilli, and J. Kastovsky. 2019. Taxonomic resolution of the genus Cyanothece (Chroococcales, Cyanobacteria), with a treatment on Gloeothece and three new genera, Crocosphaera, Rippkaea, and Zehria. Journal of Phycology 55 (3): 578-610.

Masó, M., and E. Garcés. 2006. Harmful microalgae blooms (HAB); problematic and conditions that induce them. Marine Pollution Bulletin 53 (10-12): 620-630.

McCrackin, M.L., H.P. Jones, P.C. Jones, and D. Moreno-Mateos. 2017. Recovery of lakes and coastal marine ecosystems from eutrophication: A global meta-analysis. Limnology and Oceanography 62 (2): 507-518.

Mikkelsen, P.M., P.S. Mikkelsen, and D.J. Karlen. 1995. Molluscan biodiversity in the Indian River Lagoon, Florida. Bulletin of Marine Science 57: 94-127.

Møhlenberg, F., and H.U. Riisgård. 1978. Efficiency of particle retention in 13 species of suspension feeding bivalves. Ophelia 17 (2): 239-246.

Montagna, P., D. Stockwell, and R. Kalke. 1993. Dwarf surfclam Mulinia lateralis (Say, 1822) populations and feeding during the Texas brown tide event. Journal of Shellfish Research 12: 433-442.

Newell, R.I.E. 2004. Ecosystem influences of natural and cultivated populations of suspension-feeding bivalve molluscs: A review. Journal of Shellfish Research 23: 51-61.

Norkko, A., J.E. Hewitt, S.F. Thrush, and G.A. Funnell. 2001. BenthicPelagic coupling and suspension-feeding bivalves: Linking sitespecific sediment flux and biodeposition to benthic community structure. Limnology and Oceanography 46 (8): 2067-2072.
Nübel, U., F. Garcia-Pichel, and G. Muyzer. 1997. PCR primers to amplify $16 \mathrm{~S}$ rRNA genes from cyanobacteria. Applied and Environmental Microbiology 63 (8): 3327-3332.

Paerl, H.W., and V.J. Paul. 2012. Climate change: Links to global expansion of harmful cyanobacteria. Water Research 46 (5): 1349-1363.

Parker, R.H. 1959. Macro-invertebrate assemblages of Central Texas coastal bays and Laguna Madre. Bulletin of the American Association of Petroleum Geologists 43: 2100-2166.

Phlips, E. J., and S. Badylak. 2013. Phytoplankton abundance and composition in the Indian River Lagoon, 2011-2012. St. Johns River Water Management District, special publication 2013-SP3. Palatka, Florida.

Phlips, E.J., S. Badylak, M. Christman, J. Wolny, J. Brame, J. Garland, L. Hall, J. Hart, J. Landsberg, M. Lasi, J. Lockwood, R. Paperno, D. Scheidt, A. Staples, and K. Steidinger. 2011. Scales of temporal and spatial variability in the distribution of harmful algae species in the Indian River Lagoon, Florida, USA. Harmful Algae 10 (3): 277290.

Phlips, E.J., S. Badylak, J. Hart, D. Haunert, J. Lockwood, K. O’Donnell, D. Sun, P. Viveros, and M. Yilmaz. 2012. Climatic influences on autochthonous and allochthonous phytoplankton blooms in a subtropical estuary, St. Lucie Estuary, Florida, USA. Estuaries and Coasts 35 (1): 335-352.

Phlips, E.J., S. Badylak, M.A. Lasi, R. Chamberlain, W.C. Green, L.M. Hall, J.A. Hart, J.C. Lockwood, J.D. Miller, L.J. Morris, and J.S. Steward. 2015. From red tides to green and brown tides: Bloom dynamics in a restricted subtropical lagoon under shifting climatic conditions. Estuaries and Coasts 38 (3): 886-904.

Phlips, E. J., S. Badylak, and N. Nelson. 2019. Harmful algal blooms in the Indian River Lagoon, north. Annual report to the Indian River Lagoon National Estuarine Program, contract 2018-03. Sebastian, Florida.

Phlips, E.J., S. Badylak, N.G. Nelson, and K.E. Havens. 2020. Hurricanes, El Niño and harmful algal blooms in two sub-tropical Florida estuaries: Direct and indirect impacts. Scientific Reports 10: $1-12$.

Pinckney, J.L., H.W. Paerl, P. Tester, and T.L. Richardson. 2001. The role of nutrient loading and eutrophication in estuarine ecology. Environmental Health Perspectives 109: 699-706.

Ricciardi, A., R.J. Neves, and J.B. Rasmussen. 1998. Impending extinctions of North American freshwater mussels (Unionoida) following the zebra mussel (Dreissena polymorpha) invasion. Journal of Animal Ecology 67 (4): 613-619.

Riisgård, H.U. 1988. Efficiency of particle retention and filtration rate in 6 species of Northeast American bivalves. Marine Ecology Progress Series 45: 217-223.

Riisgård, H.U. 2001. On measurement of filtration rates in bivalves - the stony road to reliable data: Review and interpretation. Marine Ecology Progress Series 211: 275-291.

Rosa, M., B.A. Holohan, S.E. Shumway, S.G. Bullard, G.H. Wikfors, S. Morton, and T. Getchis. 2013. Biofouling ascidians on aquaculture gear as potential vectors of harmful algal introductions. Harmful Algae 23: 1-7.

Rosa, M., J.E. Ward, B.A. Holohan, S.E. Shumway, and G.H. Wikfors. 2017. Physicochemical surface properties of microalgae and their combined effects on particle selection by suspension-feeding bivalve molluscs. Journal of Experimental Marine Biology and Ecology 486: 59-68.

Rose, J.M., S.B. Bricker, M.A. Tedesco, and G.H. Wikfors. 2014. A role for shellfish aquaculture in coastal nitrogen management. Environmental Science and Technology 48 (5): 2519-2525.

Sauvage, T., W.E. Schmidt, S. Suda, and S. Fredericq. 2016. A metabarcoding framework for facilitated survey of endolithic phototrophs with tufA. BMC Ecology 16: 1-21.

Sherwood, A., M. Dittbern, E. Johnston, and K. Conklin. 2017. A metabarcoding comparison of windward and leeward airborne algal 
diversity across the Ko'olau mountain range on the island of O'ahu, Hawai'i. Journal of Phycology 53 (2): 437-445.

Shumway, S.E., T.L. Cucci, R.C. Newell, and C.M. Yentsch. 1985. Particle selection, ingestion, and absorption in filter-feeding bivalves. Journal of Experimental Marine Biology and Ecology 91 (1-2): 77-92.

Sime, P. 2005. St. Lucie estuary and Indian River Lagoon conceptual ecological model. Wetlands 25 (4): 898-907.

Smith, V.H., and D.W. Schindler. 2009. Eutrophication science: Where do we go from here? Trends in Ecology and Evolution 24 (4): 201207.

Sousa, R., J.L. Gutiérrez, and D.C. Aldridge. 2009. Non-indigenous invasive bivalves as ecosystem engineers. Biological Invasions 11 (10): 2367-2385.

St Johns River Water Management District (SJRWMD). 2012. Indian River Lagoon 2011 Superbloom Plan of Investigation.

Steward, J.S., and W.C. Green. 2007. Setting load limits for nutrients and suspended solids based upon seagrass depth-limit targets. Estuaries and Coasts 30 (4): 657-670.

Strom, S.L., B. Brahamsha, K.A. Fredrickson, J.K. Apple, and A.G. Rodríguez. 2012. A giant cell surface protein in Synechococcus WH8102 inhibits feeding by a dinoflagellate predator. Environmental Microbiology 14 (3): 807-816.

Sunda, W.G., E. Graneli, and C.J. Gobler. 2006. Positive feedback and the development and persistence of ecosystem disruptive algal blooms. Journal of Phycology 42 (5): 963-974.
Swain, H.M. 1995. Reconciling rarity and representation: A review of listed species in the Indian River Lagoon. Bulletin of Marine Science 57: 252-266.

Uyeda, J.C., L.J. Harmon, and C.E. Blank. 2016. A comprehensive study of cyanobacterial morphological and ecological evolutionary dynamics through deep geologic time. PLoS One 11: 1-32.

Ward, J.E., and S.E. Shumway. 2004. Separating the grain from the chaff: Particle selection in suspension- and deposit-feeding bivalves. Journal of Experimental Marine Biology and Ecology 300 (1-2): 83-130.

Wendling, C.C., and K.M. Wegner. 2015. Adaptation to enemy shifts: Rapid resistance evolution to local Vibrio spp. in invasive pacific oysters. Proceedings of the Royal Society B: Biological Sciences 282: 20142244.

Whitall, D., S. Bricker, J. Ferreira, A.M. Nobre, T. Simas, and M. Silva. 2007. Assessment of eutrophication in estuaries: Pressure-stateresponse and nitrogen source apportionment. Environmental Management 40 (4): 678-690.

Widdows, J., P. Fieth, and C.M. Worrall. 1979. Relationships between seston, available food and feeding activity in the common mussel Mytilus edulis. Marine Biology 50 (3): 195-207.

Wilson, C., L. Scotto, J. Scarpa, A. Volety, S. Laramore, and D. Haunert. 2005. Survey of water quality, oyster reproduction and oyster health status in the St. Lucie Estuary. Journal of Shellfish Research 24: $157-165$. 